\title{
Understory community shifts in response to repeated fire and fire surrogate treatments in the southern Appalachian Mountains, USA
}

\author{
Emily C. Oakman ${ }^{1}$, Donald L. Hagan ${ }^{1 *}$ (D) Thomas A. Waldrop ${ }^{2}$ and Kyle Barrett ${ }^{1}$
}

\begin{abstract}
Background: Decades of fire exclusion in the southern Appalachian Mountains, USA, has led to changing forest structure and species composition over time. Forest managers and scientists recognize this and are implementing silvicultural treatments to restore forest communities. In this study, conducted at the southern Appalachian Fire and Fire Surrogate Study site in Green River Game Land, North Carolina, USA, we assessed the effects of four fuelreduction methods (burned four times, $\mathrm{B}$; mechanical treatment two times, M; mechanical treatment two times plus burned four times, $\mathrm{MB}$; and control, C) on the changes in understory community from pre-treatment to posttreatment years (2001 to 2016). We used non-metric multidimensional scaling (NMDS) to determine overall understory community heterogeneity, agglomerative hierarchical cluster analyses (AHCA) to determine finer-scale changes in understory community structure, and indicator species analyses (ISA) to identify the species that were associated with the different fuel reduction treatments over time.

Results: The NMDS ordination showed little separation between treatment polygons. The AHCA resulted in two main categories of understory species responses based on how treatment plots clustered together: (1) species apparently unaffected by the treatments (i.e., no treatment pattern present within cluster); and (2) species that responded to $B, M$, or $M B$ treatments (i.e., pattern of treatment plots present within cluster). Nearly half (49.2\%) of tree-species plots clustered based on treatments; $60 \%$ of shrub-species plots clustered based on treatments; and $64 \%$ of herbaceous-species plots clustered based on treatments. Many plots clustered similarly in response to firerelated treatments (B and $M B)$. The ISA identified 11 total tree species: three in $B$, one in $M$, and seven in $M B$; six total shrub species: two in $M$, and four in $M B$, and 17 total herbaceous species or genera: one in $C$, and 16 in $M B$.

Conclusion: Fire and fire surrogate treatments did not dramatically shift understory composition after 15 years. However, certain ruderal and early seral species responded positively to $M B$, which was the most intensive treatment. Modest understory community changes were also observed in B, suggestive of early signs of shifting composition toward a more open forest community after four burns.
\end{abstract}

Keywords: fire surrogates, hardwoods, herbaceous, oaks, pines, shrubs, understory vegetation

\footnotetext{
* Correspondence: dhagan@clemson.edu

${ }^{1}$ Department of Forestry and Environmental Conservation, Clemson

University, 202 Lehotsky Hall, Clemson, South Carolina 29634-0331, USA

Full list of author information is available at the end of the article
}

Springer Open (c) The Author(s). 2021 Open Access This article is licensed under a Creative Commons Attribution 4.0 International License, which permits use, sharing, adaptation, distribution and reproduction in any medium or format, as long as you give appropriate credit to the original author(s) and the source, provide a link to the Creative Commons licence, and indicate if changes were made. The images or other third party material in this article are included in the article's Creative Commons licence, unless indicated otherwise in a credit line to the material. If material is not included in the article's Creative Commons licence and your intended use is not permitted by statutory regulation or exceeds the permitted use, you will need to obtain permission directly from the copyright holder. To view a copy of this licence, visit http://creativecommons.org/licenses/by/4.0/. 


\section{Resumen}

Antecedentes: Décadas de exclusión del fuego en las montañas Apalaches del sur, EEUU, han conducido a cambiar, a través del tiempo, la estructura y composición de especies. Los gestores de recursos y científicos reconocen esto y están implementando tratamientos silvícolas para restaurar las comunidades forestales. En este estudio, conducido en el llamado sitio de los Fuegos y Sustitutos del Fuego de los Apalaches, en las tierras de caza del Río Verde (Green River Game Land), Carolina del Norte, EEUU, determinamos los efectos de cuatro métodos de reducción de combustible (quemado cuatro veces, B; tratamiento mecánico dos veces, M; tratamiento mecánico dos veces más cuatro quemas, $\mathrm{MB}$, y control, C), sobre los cambios en la comunidad del sotobosque desde el año del pretratamiento al del postratamiento (2001 al 2016). Usamos el escalado multidimensional no-métrico (NMDS) para determinar la heterogeneidad total de la comunidad de sotobosque, análisis agrupado de clúster (AHCA) para determinar los cambios a escala fina en la estructura de la comunidad de sotobosque, y un indicador de análisis de especies (ISA) para identificar las especies que estaban asociadas a los diferentes tratamientos de reducción del combustible en el tiempo.

Resultados: La ordenación del NMDS mostró una pequeña separación entre polígonos de tratamientos. El AHCA resultó en dos categorías principales de respuesta de las especies del sotobosque basadas en cómo los tratamientos estaban agrupados en clústeres: (1) especies aparentemente no afectadas por los tratamientos (i.e., no había un patrón presente dentro del clúster); y (2) las especies que respondieron a los tratamientos B, M, o MB (i.e., con un patrón de parcelas presentes dentro del clúster). Aproximadamente la mitad (49,2\%) de las parcelas con especies de árboles se agruparon en clústeres basados en los tratamientos; el 60\% de las especies de arbustos se agruparon también en clústeres basados en los tratamientos; y el 64\% de las herbáceas también lo hicieron en clústeres basados en los tratamientos. Muchas parcelas se agruparon en clústeres similares en respuesta a los tratamientos relacionados con las quemas (B y MB). El ISA identificó un total de 11 especies de árboles: tres en B, uno en $M$, y siete en $M B$; asimismo identificó seis especies de arbustos: dos en $M$, y cuatro en $M B$, y 17 especies $O$ géneros de herbáceas: uno in $\mathrm{C}$, y 16 en MB.

Conclusiones: Las quemas y los substitutos de quema no cambiaron dramáticamente la composición del sotobosque después de 15 años. Sin embargo, algunas especies ruderales y especies serales tempranas respondieron positivamente al tratamiento $\mathrm{MB}$, que fue el más intenso. Cambios modestos de la composición del sotobosque fueron también observados en el tratamiento B, sugiriendo signos tempranos de cambios en la composición hacia una comunidad forestal más abierta luego de cuatro quemas.

\section{Abbreviations}

AHCA: Agglomerative Hierarchical Cluster Analysis

B: $\quad$ Burned four times in the dormant season

C: $\quad$ Control treatment

dbh: diameter at breast height

ISA: Indicator Species Analysis

M: $\quad$ Mechanical treatment two times

MB: $\quad$ Mechanical treatment two times and Burned four times in the dormant season

NCWRC: North Carolina Wildlife Resources Commission

NMDS: Non-metric MultiDimensional Scaling

P: $\quad$ Plot-level clusters

\section{Background}

Natural and anthropogenic disturbance regimes influence forest ecosystems by altering resource distribution, which changes vegetation structure and composition across a range of spatial and temporal scales (Pickett et al. 1999; Certini 2005). Variations in disturbance type, intensity, and frequency often create mosaics in a landscape, increasing community-level heterogeneity (Willig and Walker 1999; Greenberg et al. 2016). Repeated disturbance has shaped many complex ecosystems over time, often resulting in the development of disturbance-dependent forest communities (Horn 1974).

Historical records suggest that the consistent presence of fire in a forested landscape favors the establishment, growth, and dominance of certain plant species (Greenberg et al. 2016; Lafon et al. 2017). Thus, fire acts as a selective pressure that has driven the evolution of adaptations and physiological strategies that make them more resilient to-if not dependent upon-burning (Pyne 1997). Over time, these traits have allowed certain species to remain dominant in many fire-maintained forest communities. Since fire suppression began in the early 1900s, many forest ecosystems throughout the US have experienced increased fuel loading, increased wildfire risk, changes in vegetation composition, and landscapelevel homogenization (Huddle and Pallardy 1999; Taylor 2007). In the United States, one of the regions 
most heavily affected by fire suppression is the southern Appalachian Mountains (Garren 1943; Greenberg et al. 2016).

Characterized by extreme topography, varying soil types, and large precipitation gradients, the southern Appalachian Mountain region supports high levels of biodiversity and heterogeneity (Van Lear and Waldrop 1989; Waldrop et al. 2014). However, these complexitiesin concert with extensive exurban development-also make the southern Appalachian Mountains one of the most difficult regions to manage with fire (Stanturf et al. 2002). Due to fire suppression, forests in the southern Appalachian Mountains have experienced increases in midstory and overstory density, excess fuel loading, oak (Quercus L.) and yellow pine (Pinus L. subgenus Diploxylon) regeneration failure, forest homogenization, and encroachment of mesic hardwood species (Brose and Van Lear 1998; Elliott et al. 1999). A prevalent structural shift from open pine-hardwood forests and woodlands to predominantly closed-canopy mesic forests has been documented in this region (Waldrop et al. 2008). These open forests and woodlands were typically composed of firedependent species, such as oaks, yellow pines, and diverse herbaceous flora (sedges, grasses, and forbs; Ayers and Ashe 1905). Conversely, contemporary mesic hardwood forests support the growth of fire-sensitive species like red maple (Acer rubrum L.) and yellow-poplar (Liriodendron tulipifera L.) (Nowacki and Abrams 2008). Additionally, there have been increases in flammable midstory shrubs like mountain laurel (Kalmia latifolia L.) and rhododendron (Rhododendron L. spp.), which outcompete firedependent species and create potential for higher intensity fires (Monk et al. 1985; Brose et al. 2001).

Despite a majority of vascular plant diversity being found in the understory layer, this forest component is comparatively understudied in southern Appalachian Mountain forests (Gilliam and Roberts 2003). Understory plant communities in this region can be composed of a wide array of tree, shrub, and herbaceous species regeneration (Waldrop et al. 2016; Oakman et al. 2019). This understory community is largely shaped by topography-related microsite characteristics that include abiotic factors such as microclimate, soil moisture, and soil fertility (Hutchinson et al. 1999). Repeated fires of varied intensity and severity often contribute to fluctuations in these microsite characteristics by increasing light availability from canopy openings, which alters understory community composition (Small and McCarthy 2002; Gilliam and Roberts 2003). However, many biotic factors also contribute to the formation of understory community composition (Azeria et al. 2011). For example, species-specific characteristics, like shade intolerance or prolific resprouting abilities, can influence post-fire succession (Van Lear et al. 2000; Hutchinson et al. 2005).
Many herbaceous species are classified as early seral and ephemeral, and thus respond positively-albeit temporarily-to canopy recently opened by disturbance (Roberts 2004; Hutchinson et al. 2005). These species often grow well in exposed site conditions like those created by canopy disturbance (Pavlovic et al. 2011). Understory shrubs often respond positively to cutting or dormant-season burning by sprouting after topkill (Chapman 1950; Moser et al. 1996). Competition from these shade-tolerant shrubs often impedes the regeneration of oaks, yellow pines, and herbaceous species (Monk et al. 1985). Understory hardwoods and softwoods often respond positively under open conditions in the mid- and overstory created by disturbance (Kuddes-Fischer and Arthur 2002). For example, hardwoods like oaks and softwoods like yellow pines are more tolerant of fire and respond more positively to higher intensity fire treatments than mesic hardwoods like red maple and mesic softwoods such as eastern white pine (Pinus strobus L.), particularly in drier sites (Elliott and Vose 2005; Holzmueller et al. 2014). Mesic hardwood or softwood presence reflects an increase in canopy density, as upland oaks typically regenerate well on more xeric or open sites; most mesic hardwoods are shade-tolerant or generalist species and regenerate well in a variety of site types (Huddle and Pallardy 1999; Iverson et al. 2008). Characteristics like shade and moisture tolerance influence species-level interactions, often causing shifts in species composition (Blankenship and Arthur 2006). Therefore, identifying these species traits may inform our understanding of how vegetation will respond to different fuel-reduction treatments (Keyser et al. 2008; Azeria et al. 2011).

In the southern Appalachian Mountains, prescribed fire is used for objectives such as reducing wildfire risk, creating early seral wildlife habitat, and restoring fire-adapted plant communities (Monk et al. 1985; Christensen 1993; Waldrop et al. 2016). Although the most prevalent technique for achieving these objectives in the southern Appalachian Mountains has been dormant-season burning (January through March), scientists and managers in the region have also expressed interest in using other fuel reduction methods such as mechanical treatments like mastication or chainsaw felling of ladder fuels to reverse the effects of fire suppression (Brose and Van Lear 1998; Schwilk et al. 2009). Alone or in combination with prescribed fire, these treatments have shown promise for reducing fuels and restoring a more open forest structure, but some knowledge gaps remain (Waldrop et al. 2016). These include effects on oak and pine regeneration, the control of competitive fire-sensitive species, and the effects on herbaceous vegetation (Stephens et al. 2012; Waldrop et al. 2016). 
The objective of this study was to investigate changes in understory plant communities in the southern Appalachian Mountains in response to three fuel-reduction treatments applied over the course of 15 years: burn only (B), mechanical $(\mathrm{M})$, and a combination of mechanical and burning (MB). Unburned controls (C) were also included. We used ordination and plot-level clustering techniques to characterize how understory vegetation responds to the different treatments. Additionally, we used an indicator species analysis to identify species that were most strongly associated with the treatments. We hypothesized that, after 15 years, there would be a distinctive vegetation "signature" for each treatment, reflected in shifts in their ordination polygons, and vegetation similarities causing plots to cluster together by treatment. Further, we hypothesized that each treatment would contain certain indicator species-species common in that treatment but rare in others-and for the treatments that involved fire $(\mathrm{MB}$ and $\mathrm{B})$, ruderal, early seral, and fire-adapted species would be prevalent among them.

\section{Methods}

\section{Study area}

The study area was located in Polk County, North Carolina, USA, on the Green River Game Land, which is managed for wildlife, public recreation, timber, and other resources by the North Carolina Wildlife Resources Commission (NCWRC; Fig. 1). The Green River Game Land covers 5841 ha and is classified as a mountainous region, where elevations range from about 300 to $800 \mathrm{~m}$. Forests in the region are typical of the Southern and South-Central Oak-Pine Forest and Woodland Ecosystem macrogroup (NatureServe 2020). When the study was initiated in 2001, forests in the study area were about 80 to 120 years old and consisted of mixed xeric or mesic oak and pine species depending on the topographic position. Shortleaf pine (Pinus echinata Mill.), pitch pine (Pinus rigida Mill.) and Virginia pine (Pinus virginiana Mill.) can be found on dry ridge tops while eastern white pine (Pinus strobus) was found in moist coves. Ericaceous shrubs like mountain laurel (Kalmia latifolia) and great rhododendron (Rhododendron maximum L.), composed a dense midstory layer throughout the study area, with the former more prevalent in xeric sites and the latter more prevalent in mesic sites. Most of the soils are of the Evard series (fine-loamy, oxidic, mesic, Typic Hapludults) in areas that can be described as moderately deep, welldrained, mountain uplands. Bedrock is composed of igneous and high-grade metamorphic rocks, including mica gneiss, hornblende gneiss, and amphibolite (Web Soil Survey 2020).

\section{Study design}

This study utilized a randomized complete block design, with four treatment units in each of three replicate blocks for a total of 12 treatment sites. Each treatment site covered an average of 12 ha, which included a 4 ha buffer zone. Both the buffer zones and the treatment sites received the same experimental treatment, but no sampling plots were located within the buffer zones. Within the replicate blocks, each of the four treatment units were randomly assigned to one of the treatments: control (C), prescribed burning only (B), mechanical fuel reduction $(\mathrm{M})$, and prescribed burning plus mechanical fuel reduction (MB). Treatment units were designed to include all prevailing combinations of elevation, aspect,

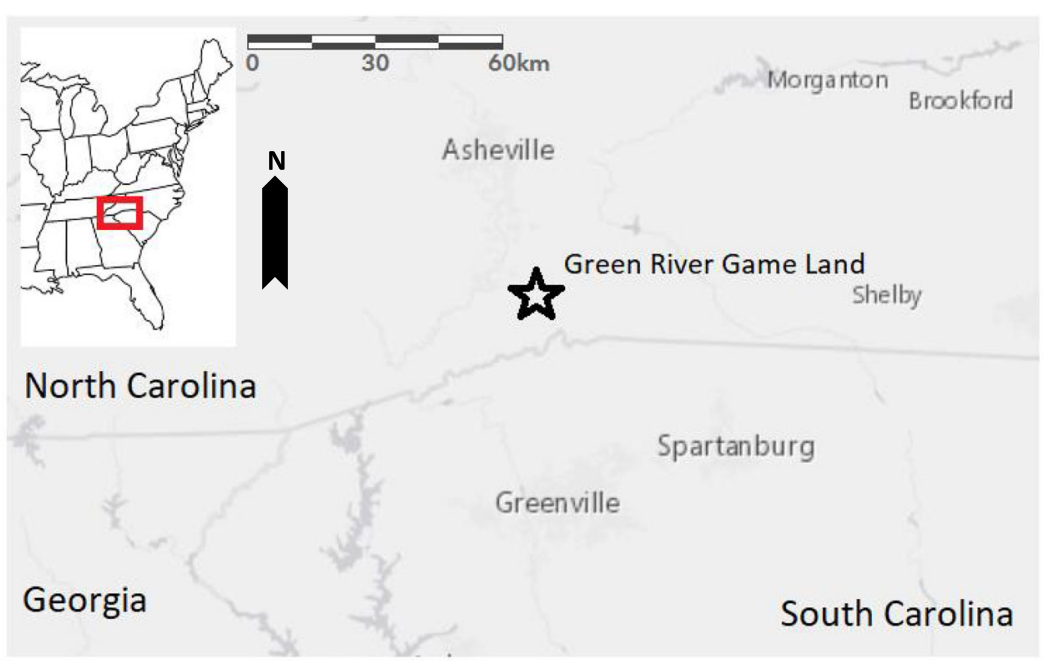

Fig. 1 Map of the location of our plant community change in response to fuel treatments study site at Green River Game Land, North Carolina, USA (2001 to 2016) 
and slope. However, these conditions varied within treatment units and were not separated for analysis (Fig. 1).

The B treatment was repeated four times by 2016, having been applied in February or March of 2003, 2006, 2012, and 2015. All fires were burned with a spot fire technique; the first was done by helicopter ignition and the others were done by hand ignition. Fire intensity was generally low, with flame lengths typically $<1$ m. Localized areas of higher fire intensity (flame lengths $>2 \mathrm{~m}$ ) were occasionally observed in MB, presumably due to higher fuel loading created by that treatment. The $M$ treatment was applied twice in the winters of 2001-2002 and 2011-2012 and included cutting of all woody vegetation $>1.4 \mathrm{~m}$ tall and $<10.2 \mathrm{~cm}$ in diameter at breast height $(\mathrm{dbh})$ with a chainsaw. The $\mathrm{MB}$ treatment was initiated with the first mechanical cutting in winter 2001-2002, treated with the two repeated prescribed burns in 2003 and 2006, included the second mechanical cutting in winter 2011-2012, and was followed by the final two prescribed burns (2012 and 2015). All treatment areas were sampled in the pre-treatment year (2001), and in the growing seasons following each treatment (2003, 2005, 2006, 2008, 2011, 2012, 2013, 2014, 2015, and 2016). Visual estimates indicated nearly $100 \%$ burn coverage in both B and $\mathrm{MB}$ treatments during each fire.

A $50 \times 50 \mathrm{~m}$ grid was established in the treatment areas, with grid points permanently marked and georeferenced. Ten 0.1 ha sample plots were established at randomly selected grid points within each treatment area (Fig. 2). The sample plots were $50 \times 20 \mathrm{~m}$ and divided into ten subplots, each about $10 \mathrm{~m}^{2}$. Within each subplot, two $1 \mathrm{~m}^{2}$ quadrats were established in the northwest and southeast corners to measure understory vegetation (<1.4 m tall) using Modified Whittaker plots (Oakman et al. 2019). Composition and abundance data were collected in each $1 \mathrm{~m}^{2}$ quadrat; this included recording the cover values of all species and additionally recording the stem counts for tree species. Cover values used in this sampling method were visually estimated and recorded as classification values: $1(<1 \%), 2$ (1 to $10 \%), 3$ (>10 to $25 \%$ ), 4 (>25 to $50 \%$ ), 5 (>50 to $75 \%$ ), and $6+$ $(>75 \%)$. To generate workable cover class values for analysis, we used the class midpoint of the percent ranges for each cover class; for example, $5.5 \%$ would be used for the cover class 2 , etc.

We acknowledge that the asynchronous nature of the experimental treatments potentially confounds our

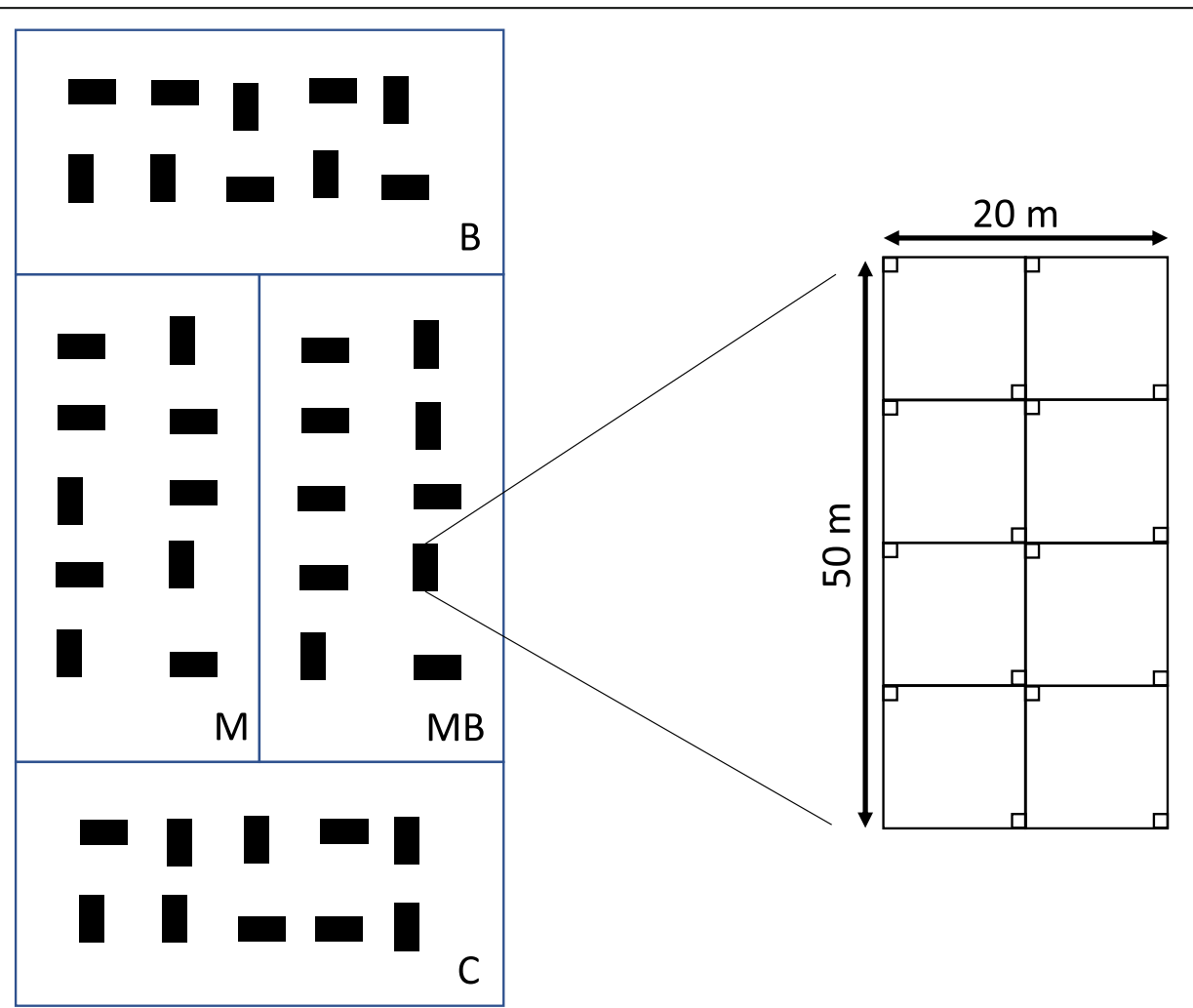

Fig. 2 Schematic of one treatment area $(n=3)$ in our study (2001 to 2016) of plant community change in response to fuel treatments in Green River Game Land, North Carolina, USA, showing the layout of the four treatments (control = C, burned four times $=$ B, mechanical removal two times of stems $<10 \mathrm{~cm}$ dbh $=M$, and combination of $M$ and $B=M B$ ) and the ten vegetation plots in each. Not to scale. Diagram on the right shows the layout of a single $20 \times 50 \mathrm{~m}$ vegetation plot, with nested $10 \times 10 \mathrm{~m}$ overstory and midstory plots and $1 \times 1 \mathrm{~m}$ understory plots 
results as time since last treatment varies (two growing seasons for B treatment; four growing seasons for $\mathrm{M}$ ). This asynchrony is an unavoidable reality of applying landscape-level treatments; it would have been logistically and financially challenging to conduct more than two mechanical treatments during the study period.

\section{Analysis}

All species in the understory $(<1.4 \mathrm{~m}$ tall) were classified into three general life form categories for analysis: trees, shrubs, and herbaceous species. Woody vines were excluded to reduce bias in the dataset, as collection methods were inconsistent in 2001 and 2016. Cover for trees, shrubs, and herbaceous species were derived from cover classification values recorded in the posttreatment year, 2016. The midpoint percentage represented in each cover class was then averaged across each plot for all treatments $(n=120$; see Oakman et al. 2019 for details). Stems per hectare (stem density) of each tree species was also calculated for each plot.

To assess understory community response to different long-term repeated fuel-reduction treatments, we first visualized the data in a non-metric multidimensional scaling (NMDS) ordination (Kruskal 1964a, b; McCune et al. 2000). Cover data from the 2016 survey period was used to construct a Bray-Curtis dissimilarity matrix for all understory species (Faith et al. 1987; Oksanen et al. 2015). Each life form category was analyzed using the metaMDS function from the vegan package in R software and overlaid in a single figure (version 3.2.2, $\mathrm{R}$ Core Team 2016). Species that occurred in less than $5 \%$ of all plots were excluded from the analysis. Stability for each life form category was assessed using the scree.plot function with 20 randomized runs and three final axes iterations. A two-dimensional solution was used in the final figure, as it was found to be sufficient for explaining similarities among species along ecological gradients. The final ordination contained three components: maximum convex polygons, species points, and axes. The convex polygons were associated with each treatment, representing variation in understory plant community responses and heterogeneity among plots in each treatment. The species points were positioned within the ordination to reflect treatments with which they are most closely associated. Axes can represent complex environmental gradients that describe separation among species points and treatment polygons.

We then conducted agglomerative hierarchical cluster analyses (AHCA), which form clusters based on shared species within our plots (McCune and Grace 2002). The cluster analyses were performed on a finer scale to show understory community shifts that may have otherwise been hidden within the NMDS ordination, allowing us to examine defined groups of species without the influence of environmental gradients. AHCAs were performed with the agnes function in the cluster package (Maechler et al. 2015). Each of the three life form categories were analyzed separately at the plot level $\left(n_{\text {trees }}=120, n_{\text {shrubs }}=120, n_{\text {herbaceous species }}=117\right)$ to compare between-plot similarity of plant composition for different life form categories (Oksanen et al. 2015). Three plots were omitted within the herbaceous species dataset due to the absence of understory vegetation in those plots. Stem density data were used in the tree species AHCA, and cover data were used in the shrub and herbaceous species AHCA. Cover was normalized, making the marginal sum of squares equal to zero for a better fitting distribution. With an AHCA technique, each plot is considered an individual cluster and therefore plots with similar species are grouped into larger clusters resulting in a single dendrogram (McCune and Grace 2002). We used Bray-Curtis as the distance metric and flexible beta linkage $(\beta=-0.25)$ as the fusion strategy to determine the appropriate number of clusters for each life form category based on local group structure (Oksanen et al. 2015). The cluster number was determined from fusion height, a visualization method that shows natural breaks in the data, indicating the highest number of plot similarities. To better explain plant community responses to the four treatments, clusters were then grouped into two descriptive categories based on the proportions of treatment plots within each cluster: (1) species apparently unaffected by the treatments, and (2) species that responded to treatments (McCune et al. 2000; GonzalezTagle et al. 2008).

Indicator species analyses (ISA) were conducted in the indicspecies package in $\mathrm{R}$ for each life form category to identify indicators of species composition shifts in response to our treatments (Dufrêne and Legendre 1997; De Cáceres and Legendre 2009). Indicator species are those that have had specificity and fidelity to a given treatment and, thus, are the most indicative members of that treatment (Costanza et al. 2017). For shrub and herbaceous species, cover data were used to calculate the highest indicator value (IVmax), $P$-value, specificity, and fidelity for each species using the multipatt function (duleg = TRUE) and strassoc function in R (De Cáceres and Legendre 2009). A species' indicator value (IV; 0 to 1 ) is the square root of the product of that species' A and B; A indicates the probability that the given species is in a given cluster when it is found, and B indicates the probability of finding the given species in a given cluster (Shearman et al. 2017). The $P$-values $(\alpha=0.05)$ represent the probability of obtaining an indicator value by chance that is equal to 1 (Kane et al. 2010). Indicator values were computed based on a Monte Carlo test with 999 permutations (McCune and Grace 2002). 


\section{Results}

\section{Non-metric multidimensional scaling (NMDS)}

The NMDS ordination was resolved by two axes, with a stress value of 0.20 , which is considered acceptable based on Clarke (1993, Fig. 3). Treatment polygons overlapped considerably within the ordination space, with relatively low distances between species. Overall, the resulting NMDS showed little separation between treatment polygons and little variability in species spread.

\section{Agglomerative hierarchical cluster analysis (AHCA)}

Considering the NMDS results, we used an AHCA to further break down vegetation life forms into discrete clusters at the plot level (P). Clustering plots with similar composition helped to describe small-scale patterns in plant community composition that may have otherwise been overlooked within the NMDS ordination (Shearman et al. 2017). These cluster-level responses were generalized into two broad categories based on species composition within the plots: (1) species apparently unaffected by the treatments (i.e., no apparent pattern in relationship to treatments; similar to C), and (2) species that responded to treatments (i.e., apparent pattern associated with treatments; different from $\mathrm{C}$ ).

Among the clusters that responded differently to $\mathrm{C}$, one or more distinct responses can be described by treatment-plot proportions (e.g., if a cluster contains B or $\mathrm{MB}$ plots). Clusters 2 and 5 in the tree dendrogram were associated with $\mathrm{C}\left(51 \%\right.$ of total plots $\left.\left[T \mathrm{P}_{\text {Total }}\right]\right)$, while clusters 1,3 , and 4 responded differently to $B, M$, and $\mathrm{MB}$ treatments $\left(49.2 \% \mathrm{TP}_{\mathrm{Total}}\right)$ (Fig. 4). Plots in cluster $1\left(T_{\mathrm{C} 1}\right)$ appeared to respond similarly to the effects of $\mathrm{B}$ and $\mathrm{MB}\left(T_{\mathrm{C} 1}=11\right.$ plots in $\mathrm{B}$, six in $\mathrm{C}$, two in $\mathrm{M}$, and 15 in $\mathrm{MB})$, plots in cluster $3\left(T_{\mathrm{C} 3}\right)$ responded similarly to the effects of $B$ (six plots in $B$, one in $C$, one in $\mathrm{M}$, and 0 in $\mathrm{MB})$, and plots in cluster $4\left(T_{\mathrm{C} 4}\right)$ responded distinctly to $M$ effects (zero plots in $B$, seven in $C$, ten in $\mathrm{M}$, and zero in $\mathrm{MB}$ ).

In the shrub dendrogram, cluster 4 responded similarly to $C\left(16 \%\right.$ of total plots $\left.\left[S \mathrm{P}_{\text {Total }}\right]\right)$, while clusters 1 , 2 , and 3 responded differently to $\mathrm{B}, \mathrm{M}$, and $\mathrm{MB}$ treatments $\left(60 \% S \mathrm{P}_{\text {Total }}\right)$ (Fig. 5). Plots in clusters $1\left(S_{\mathrm{C} 1}\right)$ and $2\left(S_{\mathrm{C} 2}\right)$ responded similarly to the effects of $\mathrm{B}$ and $\mathrm{MB}$ $\left(S_{\mathrm{C} 1}=\right.$ six plots in $\mathrm{B}$, three in $\mathrm{C}$, one in $\mathrm{M}$, and seven in $\mathrm{MB} ; S_{\mathrm{C} 2}=$ ten plots in $\mathrm{B}$, six in $\mathrm{C}$, four in $\mathrm{M}$, and nine in $\mathrm{MB})$, and plots in cluster $3\left(S_{\mathrm{C} 3}\right)$ responded distinctly

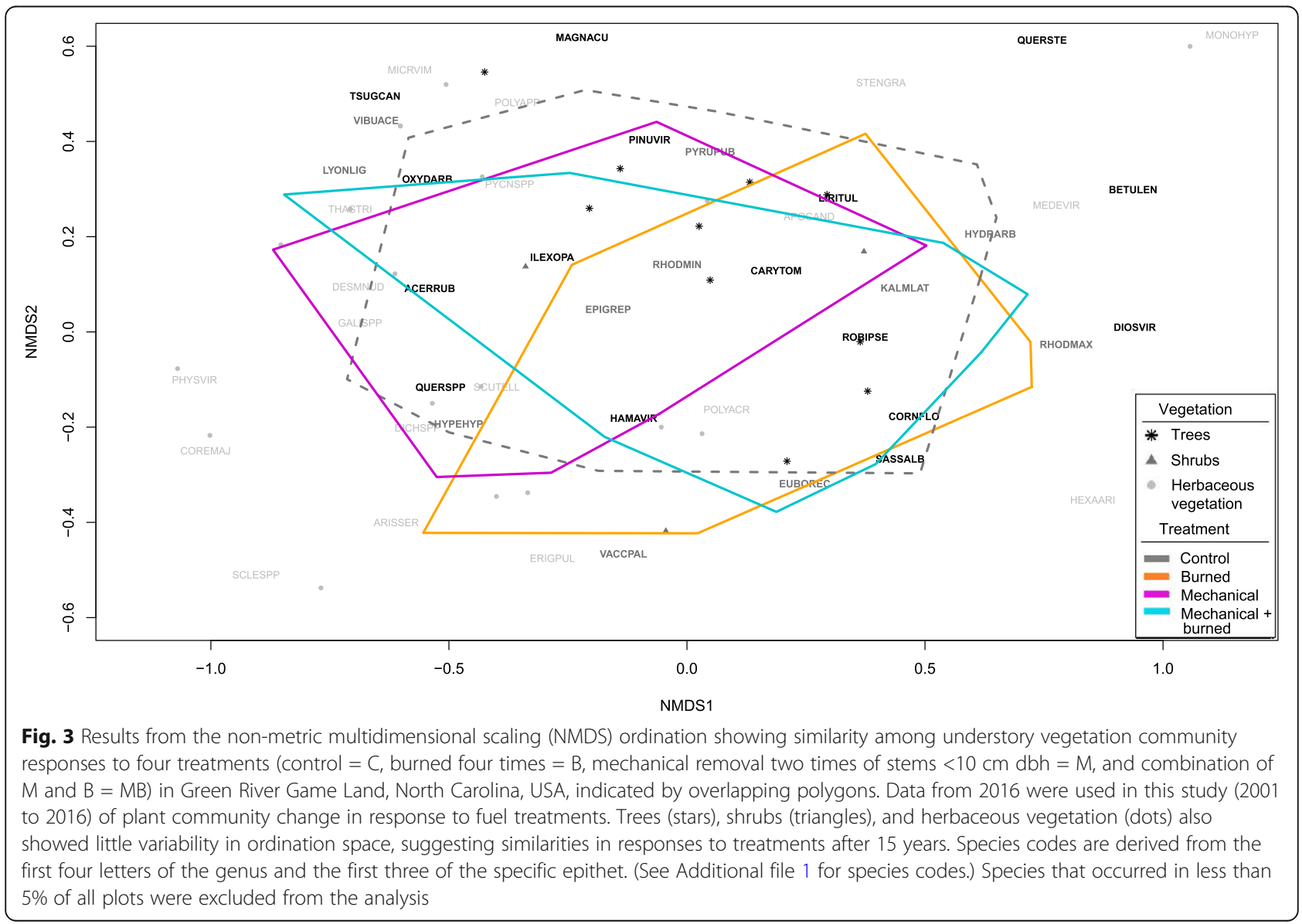




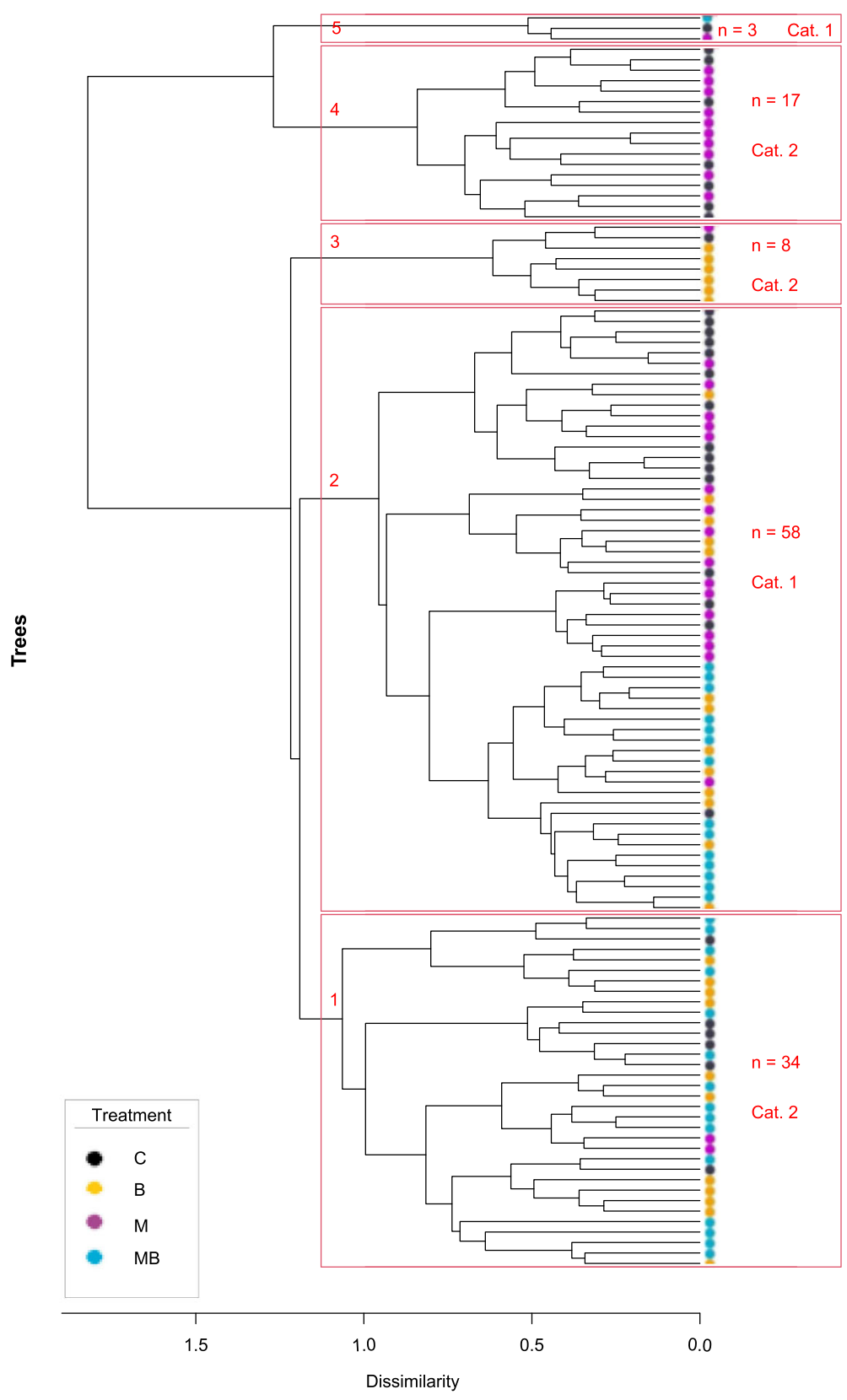

Fig. 4 A dendrogram of clustered plots $(n=120)$ derived from the agglomerative hierarchical cluster analysis (AHCA) for trees shows five distinct clusters (labeled 1 through 5) in response to treatments (control $=\mathrm{C}$, burned four times $=\mathrm{B}$, mechanical removal two times of stems $<10 \mathrm{~cm}$ dbh $=\mathrm{M}$, and combination of $\mathrm{M}$ and $\mathrm{B}=\mathrm{MB}$ ). Data from 2016 were used in this study (2001 to 2016) of plant community change in response to fuel treatments in Green River Game Land, North Carolina, USA. A Bray-Curtis approach was used as the distance metric and a flexible beta linkage was used as the fusion strategy to determine the appropriate number of clusters. The cluster number was determined from fusion height, a visualization method that shows natural breaks in the data, indicating the highest number of plot similarities. Each line on the dendrogram is denoted by orange (burned four times; B), black (control; C), purple (mechanical treatment two times; M), and blue (mechanical treatment two times plus burned four times; MB) dots that indicate which treatment was applied to that plot. Cluster 1 had 11 plots in $B$, six in $C$, two in $M$, and 15 in $M B$, categorizing it as having a different response from $C$ (category 2; Cat. 2). Cluster 2 had 13 plots in B, 15 in C, 16 in M, and 14 in MB, categorizing it as having a similar response to $C$ (category 1; Cat. 1). Cluster 3 had six plots in $B$, one in $C$, one in $M$, and 0 in $M B$, falling under category 2. Cluster 4 had zero plots in $B$, seven in $C$, ten in $M$, and zero in $M B$, falling under category 2. Cluster 5 had zero plots in $B$, one in $C$, one in $M$, and one in $M B$, falling under category 1 . The horizontal axis at the bottom of the dendrogram represents the distance or dissimilarity between clusters 


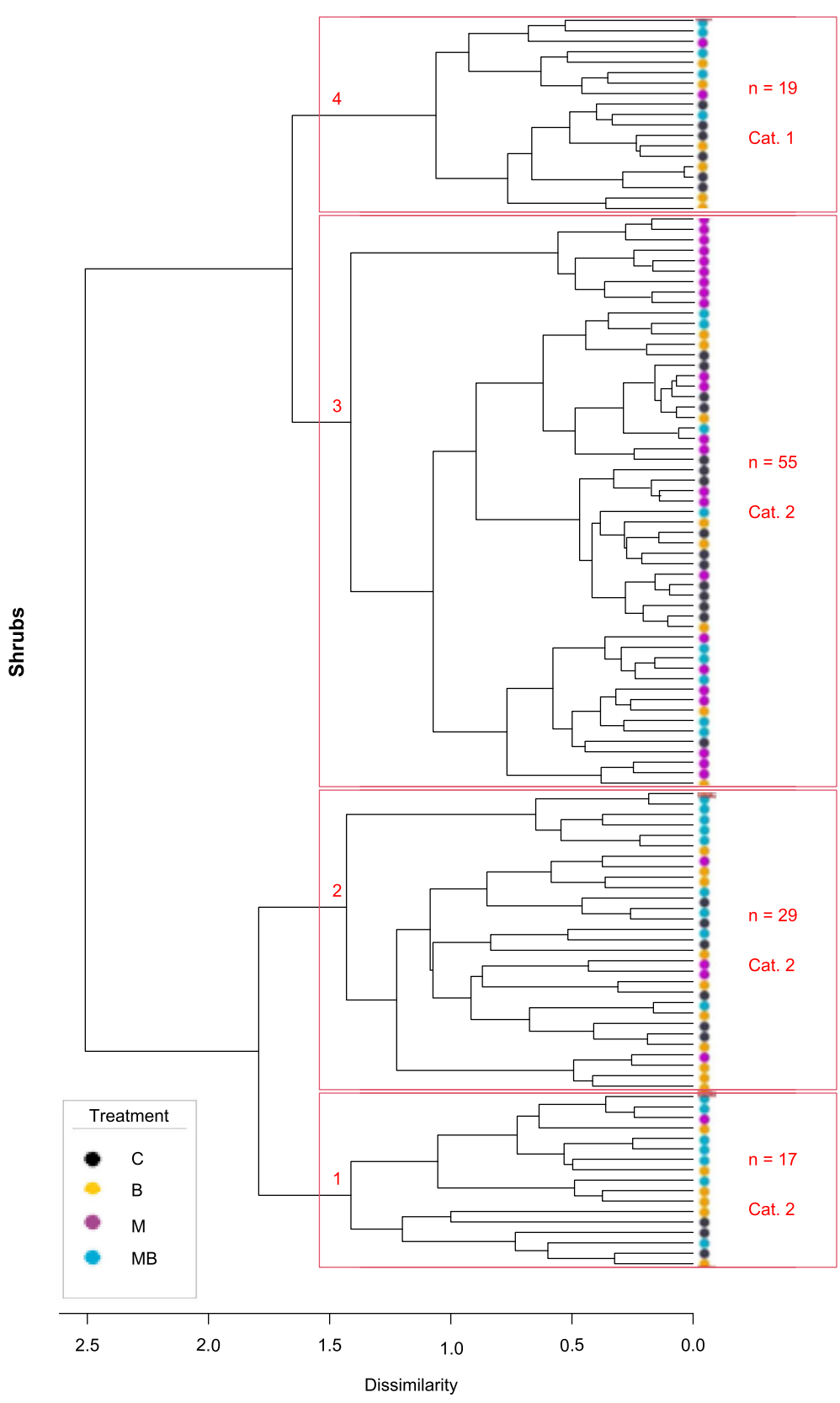

Fig. 5 A dendrogram of clustered plots $(n=120)$ derived from the agglomerative hierarchical cluster analysis (AHCA) for shrubs shows four distinct clusters (labeled 1 through 4 ) in response to treatments (control $=$ C, burned four times $=B$, mechanical removal two times of stems $<10 \mathrm{~cm}$ $\mathrm{dbh}=\mathrm{M}$, and combination of $\mathrm{M}$ and $\mathrm{B}=\mathrm{MB}$ ). Data from 2016 were used in this study (2001 to 2016) of plant community change in response to fuel treatments in Green River Game Land, North Carolina, USA. A Bray-Curtis approach was used as the distance metric and a flexible beta linkage was used as the fusion strategy to determine the appropriate number of clusters. The cluster number was determined from fusion height, a visualization method that shows natural breaks in the data, indicating the highest number of plot similarities. Each line on the dendrogram is denoted by orange (burned four times; B), black (control; C), purple (mechanical treatment two times; M), and blue (mechanical treatment two times plus burned four times; MB) dots that indicate which treatment was applied to that plot. Cluster 1 had six plots in $B$, three in $C$, one in $M$, and seven in $M B$, categorizing it as having a different response from $C$ (category 2; Cat. 2). Cluster 2 had ten plots in $B$, six in $C$, four in $M$, and nine in MB, falling under category 2. Cluster 3 had eight plots in B, 15 in C, 23 in M, and nine in MB, falling under category 2. Cluster 4 had six plots in B, six in C, two in M, and five in MB, categorizing it as having a similar response to $C$ (category 1 ; Cat. 1). The horizontal axis at the bottom of the dendrogram represents the distance or dissimilarity between clusters 


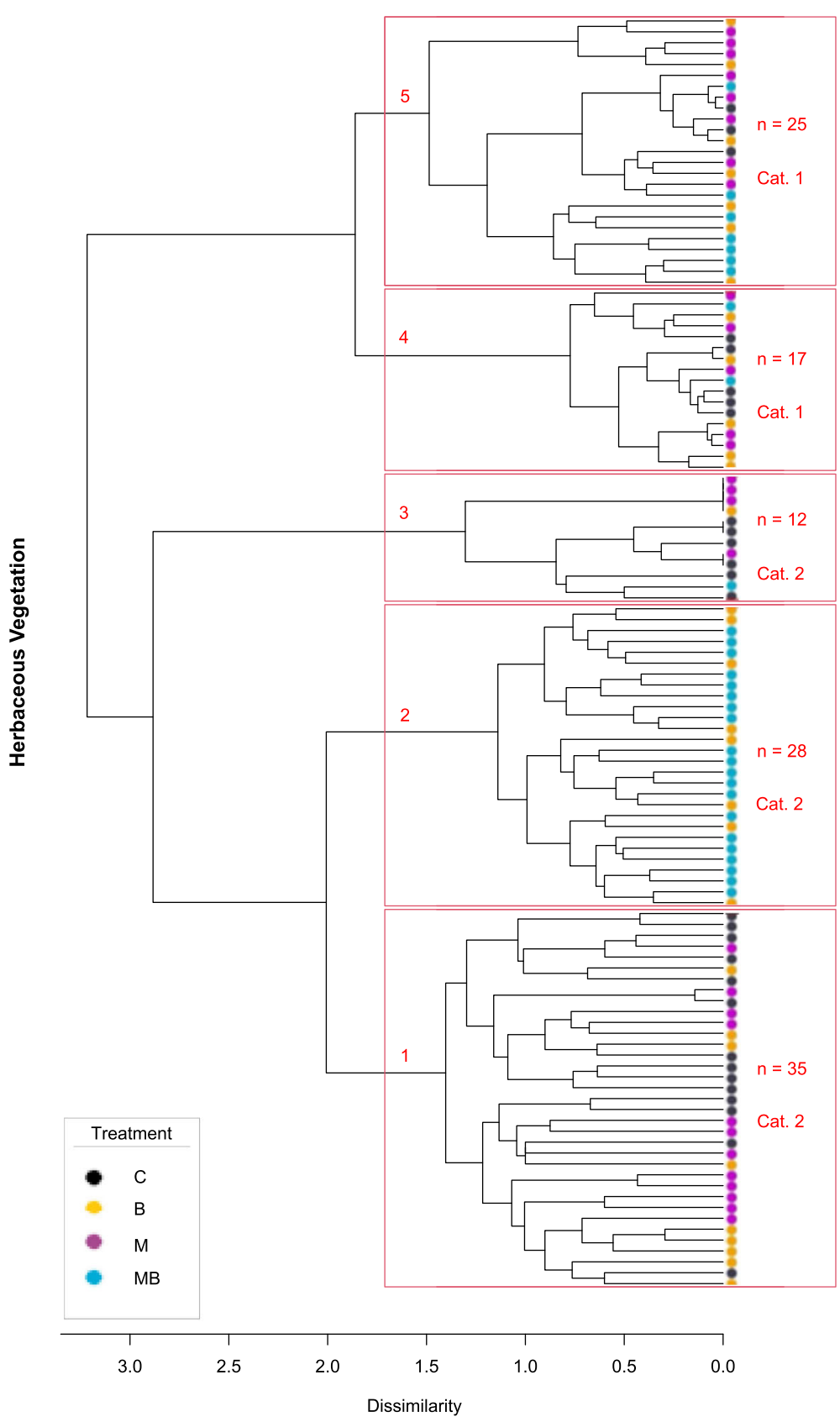

Fig. 6 A dendrogram of clustered plots $(n=117)$ derived from the agglomerative hierarchical cluster analysis (AHCA) for herbaceous vegetation shows five distinct clusters (labeled 1 through 5 ) in response to treatments (control $=C$, burned four times $=B$, mechanical removal two times of stems $<10 \mathrm{~cm}$ dbh $=\mathrm{M}$, and combination of $\mathrm{M}$ and $\mathrm{B}=\mathrm{MB}$ ). Data from 2016 were used in this study (2001 to 2016) of plant community change in response to fuel treatments in Green River Game Land, North Carolina, USA. A Bray-Curtis approach was used as the distance metric and a flexible beta linkage was used as the fusion strategy to determine the appropriate number of clusters. The cluster number was determined from fusion height, a visualization method that shows natural breaks in the data, indicating the highest number of plot similarities. Each line on the dendrogram is denoted by orange (burned four times; B), black (control; C), purple (mechanical treatment two times; M), and blue (mechanical treatment two times plus burned four times; MB) dots that indicate which treatment was applied to that plot. Cluster 1 had nine plots in B, 14 in $C_{1}, 12$ in $\mathrm{M}$, and zero in $\mathrm{MB}$, categorizing it as having a different response from $\mathrm{C}$ (category 2; Cat. 2). Cluster 2 had eight plots in $B$, zero in $C$, zero in $M$, and 20 in $M B$, falling under category 2. Cluster 3 had one plot in $B$, six in $C$, four in $M$, and one in $M B$, falling under category 2 . Cluster 4 had five plots in $B$, five in $C$, five in $M$, and two in $M B$, categorizing it as having a similar response to $C$ (category 1 ; Cat. 1). Cluster 5 had seven plots in $B$, three in $C$, eight in $M$, and seven in $M B$, falling under category 1 . The horizontal axis at the bottom of the dendrogram represents the distance or dissimilarity between clusters 
Table 1 Site specificity, fidelity, relative indicator value ( $\left(\mathrm{V}_{\text {reli }}\right.$ specificity $\times$ fidelity), abundance (stems ha ${ }^{-1}$ or percent cover), and the maximum indicator value ( $\left(V_{\max }\right)$ results from the indicator species analyses (ISA) on understory tree, shrub, and herbaceous species in our study (2001 to 2016) of plant community change in response to fuel treatments in Green River Game Land, North Carolina, USA. These results, based on 2016 data from the study, indicate species compositions in response to repeated treatments

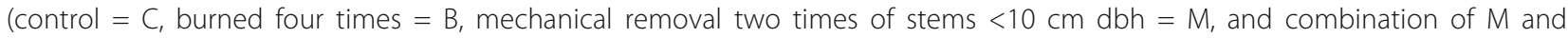
$\mathrm{B}=\mathrm{MB})$. Asterisks represent the degree of significance $\left({ }^{* *}=P<0.001,{ }^{* *}=P<0.01,{ }^{*}=P<0.05\right)$

\begin{tabular}{|c|c|c|c|c|c|c|c|}
\hline Life form & Treatment & Species & Specificity & Fidelity & IV rel & $\begin{array}{l}\text { Abundance } \\
\left(\text { stems ha }{ }^{-1} \text { ) }\right.\end{array}$ & $I V_{\max }$ \\
\hline \multirow[t]{12}{*}{ Trees } & \multirow[t]{3}{*}{ B } & Acer rubrum L. & 0.40 & 1.00 & 0.40 & 2376.40 & $0.63 * * *$ \\
\hline & & Liriodendron tulipifera $\mathrm{L}$. & 0.39 & 0.77 & 0.30 & 526.43 & $0.55 * *$ \\
\hline & & Amelanchier arborea (F. Michx.) Fernald & 0.71 & 0.33 & 0.23 & 413.89 & $0.49 * *$ \\
\hline & M & Pinus strobus L. & 0.64 & 0.20 & 0.13 & 116.67 & $0.36 *$ \\
\hline & \multirow[t]{7}{*}{$\mathrm{MB}$} & Quercus coccinea Muenchh. & 0.34 & 0.97 & 0.33 & 1360.43 & $0.58 * * *$ \\
\hline & & Sassafras albidum (Nutt.) Nees & 0.38 & 1.00 & 0.38 & 1173.89 & $0.62 * * *$ \\
\hline & & Nyssa sylvatica Marshall & 0.40 & 0.90 & 0.36 & 966.98 & $0.60 * * *$ \\
\hline & & Oxydendrum arboreum (L.) DC. & 0.49 & 0.60 & 0.29 & 838.89 & $0.54 * *$ \\
\hline & & Diospyros virginiana $\mathrm{L}$. & 0.66 & 0.30 & 0.20 & 261.10 & $0.44^{* *}$ \\
\hline & & Quercus montana Willd. & 0.37 & 0.87 & 0.32 & 1709.09 & $0.56 *$ \\
\hline & & Robinia pseudoacacia L. & 0.53 & 0.30 & 0.16 & 245.00 & $0.40 *$ \\
\hline & & & & & & $\begin{array}{l}\text { Abundance } \\
(\%)\end{array}$ & \\
\hline \multirow[t]{7}{*}{ Shrubs } & \multirow[t]{2}{*}{ M } & Rhododendron maximum $\mathrm{L}$. & 0.84 & 0.37 & 0.31 & 287.27 & $0.55 * * *$ \\
\hline & & Kalmia latifolia $\mathrm{L}$. & 0.36 & 0.87 & 0.31 & 780.66 & $0.56 * *$ \\
\hline & \multirow[t]{4}{*}{$\mathrm{MB}$} & Rhus glabra L. & 0.81 & 0.60 & 0.49 & 135.44 & $0.70 * * *$ \\
\hline & & Ceanothus americanus L. & 0.88 & 0.27 & 0.24 & 39.21 & $0.49 * * *$ \\
\hline & & Lyonia ligustrina (L.) DC. & 0.84 & 0.17 & 0.14 & 179.15 & $0.38 *$ \\
\hline & & Hypericum hypericoides (L.) Crantz & 0.56 & 0.27 & 0.15 & 20.88 & $0.39 *$ \\
\hline & & & & & & $\begin{array}{l}\text { Abundance } \\
\text { (\%) }\end{array}$ & \\
\hline \multirow[t]{17}{*}{ Herbaceous vegetation } & C & Arundinaria appalachiana Triplett, Weakley \& L.G. Clark & 0.83 & 0.23 & 0.19 & 111.50 & $0.44^{* *}$ \\
\hline & \multirow[t]{16}{*}{$\mathrm{MB}$} & Rubus argutus Link & 0.67 & 0.70 & 0.47 & 122.93 & $0.69 * * *$ \\
\hline & & Coreopsis major Walter & 0.73 & 0.77 & 0.56 & 91.41 & $0.75 * * *$ \\
\hline & & Carex L. sp. & 0.48 & 0.73 & 0.35 & 83.50 & $0.60 * * *$ \\
\hline & & Dichanthelium (Hitchc. \& Chase) Gould spp. & 0.46 & 0.97 & 0.45 & 71.57 & $0.67 * * *$ \\
\hline & & Schizachyrium scoparium (Michx.) Nash & 0.68 & 0.50 & 0.34 & 69.86 & $0.58 * * *$ \\
\hline & & Helianthus divaricatus L. & 0.98 & 0.27 & 0.26 & 53.50 & $0.51 * * *$ \\
\hline & & Potentilla canadensis L. & 0.56 & 0.53 & 0.30 & 47.18 & $0.55 * * *$ \\
\hline & & Lespedeza bicolor Turcz. & 1.00 & 0.20 & 0.20 & 37.17 & $0.45 * * *$ \\
\hline & & Solidago L. sp. & 0.60 & 0.33 & 0.20 & 70.08 & $0.45 * *$ \\
\hline & & Desmodium nudiflorum (L.) DC. & 0.64 & 0.43 & 0.28 & 52.79 & $0.51 * *$ \\
\hline & & Scleria P.J.Bergius sp. & 0.55 & 0.53 & 0.29 & 23.50 & $0.54 * *$ \\
\hline & & Conyza canadensis $L$. & 0.70 & 0.30 & 0.21 & 5.46 & $0.46 * *$ \\
\hline & & Erechtites hieraciifolius (L.) Raf. ex DC. & 0.73 & 0.27 & 0.20 & 3.00 & $0.44 * *$ \\
\hline & & Piptochaetium avenaceum (L.) Parodi & 0.63 & 0.23 & 0.14 & 43.00 & $0.39 *$ \\
\hline & & Houstonia purpurea $\mathrm{L}$. & 0.62 & 0.43 & 0.27 & 30.50 & $0.46 *$ \\
\hline & & Cassia L. sp. & 0.90 & 0.13 & 0.12 & 4.50 & $0.35 *$ \\
\hline
\end{tabular}


to the effects of $\mathrm{M}\left(S_{\mathrm{C} 3}=\right.$ eight plots in $\mathrm{B}, 15$ in $\mathrm{C}, 23$ in $\mathrm{M}$, and nine in $\mathrm{MB}$ ).

In the herbaceous species dendrogram, clusters 4 and 5 responded similarly to $\mathrm{C}$ ( $36 \%$ of total plots $\left.\left[H \mathrm{P}_{\text {Total }}\right]\right)$, while clusters 1,2 , and 3 responded distinctly to $\mathrm{MB}, \mathrm{B}$, and $\mathrm{M}$ treatments $\left(64 \% H \mathrm{P}_{\text {Total }}\right)$ (Fig. 6). Cluster $1\left(H_{\mathrm{C} 1}\right)$ responded distinctly to $\mathrm{B}$ and $\mathrm{M}$ effects $\left(H_{\mathrm{C} 1}=\right.$ nine plots in $\mathrm{B}, 14$ in $\mathrm{C}, 12$ in $\mathrm{M}$, and zero in $\mathrm{MB})$, cluster 2 $\left(H_{\mathrm{C} 2}\right)$ responded distinctly to $\mathrm{MB}$ effects $\left(H_{\mathrm{C} 2}=\right.$ eight plots in $B$, zero in $C$, zero in $M$, and 20 in $M B$ ), and cluster $3\left(H_{\mathrm{C} 3}\right)$ responded similarly to $\mathrm{B}$ and $\mathrm{MB}$ effects $\left(H_{\mathrm{C} 3}=\right.$ one plot in $\mathrm{B}$, six in $\mathrm{C}$, four in $\mathrm{M}$, and one in $\mathrm{MB})$.

\section{Indicator species analysis (ISA)}

The ISA for trees identified 11 indicator species total: three species in B (Acer rubrum, Amelanchier arborea [F. Michx.] Fernald, and Liriodendron tulipifera), one species in M (Pinus strobus), seven species in MB (Sassafras albidum [Nutt.] Nees, Diospyros virginiana L., Nyssa sylvatica Marshall, Oxydendrum arboreum [L.] DC., Quercus coccinea Muenchh., Q. montana Willd., and Robinia pseudoacacia L.), and no species in C (Table 1). The ISA for shrubs identified six indicator species total: two species in M (Kalmia latifolia and Rhododendron maximum), four species in MB (Ceanothus americanus L., Hypericum hypericoides [L.] Crantz, Lyonia ligustrina [L.] DC., and Rhus glabra L.), and no species in B or C (Table 1). The ISA for herbaceous species identified a total of 17 indicator species or genera: one species in C (Arundinaria appalachiana Triplett, Weakley \& L.G. Clark), 16 species or genera in MB (Dichanthelium [Hitchc. \& Chase] Gould spp., Piptochaetium avenaceum [L.] Parodi, Schizachyrium scoparium [Michx.] Nash, Scleria P.J.Bergius spp.; Carex L. sp., Cassia L. sp., Conyza canadensis L., Coreopsis major Walter, Desmodium nudiflorum [L.] DC., Erechtites hieraciifolius [L.] Raf. ex DC., Helianthus divaricatus L., Houstonia purpurea L., Lespedeza bicolor Turcz., Potentilla canadensis L., Rubus argutus Link, and Solidago L. spp.), and no species in B or M (Table 1).

\section{Discussion}

\section{Non-metric multidimensional scaling (NMDS)}

Contrary to our hypothesis, the overlapping treatment polygons suggest similarity in post-treatment species composition because treatments share many species. Most of the tree, shrub, and herbaceous species showed little separation in ordination space, suggesting somewhat differential but mostly shared responses to treatments. Additionally, the relatively short distances between species made the ecological trends represented by each axis difficult to interpret. Little separation between treatment polygons and little variability in species spread was also observed when all species were included in the ordination. This suggests that there may not have been a strong species response to the treatments and that further analyses may be necessary to examine the changes that may have occurred.

\section{Agglomerative hierarchical cluster analysis (AHCA)}

While the NMDS showed only modest differences in understory community composition between treatments, the results of the AHCA supported our hypothesis, showing evidence of treatment effects within life form categories. The largest portion of clusters was associated with category 1 (those with no apparent pattern in relationship to treatments; similar to $C$ ), suggestive of the predominance of generalist species that are largely unaffected by treatment type. However, some clusters responded similarly to fire-related disturbance (B or $\mathrm{MB}$ ), suggestive of modest compositional shifts to a more ruderal or early seral plant community in those treatments. This may predominantly be due to the overstory and midstory canopy openings that were mostly created by $\mathrm{MB}$ treatments (due to localized areas of higher-intensity fire in $\mathrm{MB}$ ), as reported in Waldrop et al. (2016). However, identifying individual species that are driving these responses would give more indication of compositional and abiotic changes in response to repeated treatments (Keyser et al. 2008; Azeria et al. 2011). Overall, many clusters showed similarities in vegetation response among treatments; however, the few clusters that showed divergence from the $C$ treatments suggest only subtle and perhaps localized treatment effects on understory vegetation.

\section{Indicator species analysis (ISA)}

Within the tree group, the indicator species in B (Acer rubrum, Amelanchier arborea, and Liriodendron tulipifera) indicated that $B$ sites were largely differentiated by mesic species that grow well under conditions created by lowintensity prescribed fire. Four repeated dormant-season burns did not appear to be sufficient for meeting the management objective of creating understory conditions that favor oak and yellow pine recruitment (Kuddes-Fischer and Arthur 2002; Dolan and Parker 2004). However, it is possible that fires of greater intensity or in a different season could produce a different result. The indicator species in $M$ (Pinus strobus) suggests that these sites were differentiated by white pine, a mesic species (Phillips et al. 2007). This also suggests that long-term $M$ treatments may not create conditions that are favorable for fire-tolerant species as they need a more open canopy and drier microsite conditions to grow optimally (Vose et al. 1993). The indicator species in MB (Sassafras albidum, Diospyros virginiana, Nyssa sylvatica, Oxydendrum arboreum, Quercus coccinea, Q. montana, and Robinia pseudoacacia) indicate that 
these sites are differentiated by more xeric species, many of which are light-responsive and grow well under more open conditions (Clinton and Vose 2000). More specifically, Quercus montana, Q. coccinea, and Sassafras albidum and Robinia pseudoacacia grow best in open, dry conditions, suggestive of some level of mesophication reversal in MB (Boring and Swank 1984; Dey and Hartman 2005), perhaps caused by greater fire intensity in that treatment.

Within the shrub group, the indicator species in $\mathrm{M}$ (Kalmia latifolia and Rhododendron maximum) indicate that these sites are differentiated by ericaceous shrubs that grow well in shade, prefer mesic conditions $(R$. maximum), and resprout prolifically when cut (Vose et al. 1993). This suggests that $M$ treatments may not have reduced ericaceous shrub competitors, which is a priority management objective in this region (Waldrop et al. 2016). The indicator species in MB (Ceanothus americanus, Hypericum hypericoides, Lyonia ligustrina, and Rhus glabra) suggests that these sites are differentiated by more light-responsive and opportunistic species that grow well in open, xeric sites (Hutchinson et al. 2005; Keyser et al. 2008).

Within the herbaceous group, the indicator species in C (Arundinaria appalachiana) was widely prevalent, whereas it was sparse in other treatments. This suggests that Arundinaria appalachiana may be sensitive to disturbance, or that it is a poor competitor in a postdisturbance environment. The indicator species in $\mathrm{MB}$ suggest a high level of understory diversity, with five graminoids (Dichanthelium spp., Piptochaetium avenaceum, Schizachyrium scoparium, Carex sp., and Scleria spp.), and 11 forb species (Cassia sp., Conyza canadensis, Coreopsis major, Desmodium nudiflorum, Erechtites hieraciifolius, Helianthus divaricatus, Houstonia purpurea, Lespedeza bicolor, Potentilla canadensis, Rubus argutus, and Solidago sp.), three of which are nitrogen-fixing (Cassia sp., Desmodium nudiflorum, and Lespedeza bicolor). This suggests that MB treatments are facilitating the establishment of a different set of species that are largely unique to this treatment (Burton et al. 2011). The indicator species in MB are also suggestive of a shift towards annual or early seral species, which is a desirable outcome for fire managers (Waldrop et al. 2016). The forbs, mainly in the Asteraceae family, often respond well to larger disturbances, indicating larger openings in the canopy and midstory (Hutchinson et al. 2005). Many graminoids, such as Schizachyrium scoparium, often grow well in disturbed sites with high light availability (Peterson et al. 2007).

\section{Conclusions}

Four fires and two mechanical treatments over the course of 15 years resulted in only modest changes in understory vegetation composition, as observed from our NMDS results. Nonetheless, we observed the greatest degree of change, including an increase in early seral, fire-adapted, or fire-dependent understory species in the most intensive treatment (MB). This treatment likely resulted in the greatest increases in understory light availability, as well as reductions in litter and duff necessary for the establishment of these species. Further research, which should include the continued frequent application of prescribed fire, should be conducted on the longer-term effects of B to determine if the effects of B will eventually approach those of MB. Additionally, the differences in understory responses observed between $\mathrm{M}$ and $\mathrm{B}$ treatments suggests that $M$ is only somewhat of a surrogate for B. The results of this study will prove valuable for managers in the southern Appalachian Mountain region who are considering using fire and fire surrogate treatments to manipulate vegetation composition.

\section{Supplementary Information}

The online version contains supplementary material available at https://doi. org/10.1186/s42408-021-00097-1.

Additional file 1. Species codes and scientific names for all taxa shown in the non-metric multidimensional scaling figure (Fig. 3). Data from 2016 were used in this study (2001 to 2016) of plant community change in response to fuel treatments in Green River Game Land, North Carolina, USA.

\begin{abstract}
Acknowledgements
In addition to the funding sources listed above, we would like to acknowledge the current and past students, researchers, and agency employees that established the study plots, measured vegetation, and assisted with data management and analysis. We are grateful to each, but special thanks go to M. Akridge, G. Chapman, E. Gambrell, S. McKinney, H. Mohr, R. Phillips, D. Simon, and M. Smith. Feedback from two anonymous reviewers greatly improved the original manuscript. The manuscript is technical contribution number 6937 of the Clemson University Experiment Station. This material is based upon work supported by USDA National Institute of Food and Agriculture, under project number SC-1700514.
\end{abstract}

\section{Authors' contributions}

ECO conducted the data analyses and wrote the first draft of the manuscript. TAW conceived of the study, secured initial and continued funding, and provided pre-fire data from 2001. DLH, TAW, and KB assisted with data analysis and edited the manuscript. All authors read and approved the final manuscript.

\section{Funding}

This study was made possible by generous funding and support from the National Fire Plan (NFP), Joint Fire Science Program (JFSP), US Forest Service, and the North Carolina Wildlife Resources Commission. The NFP and JFSP provided funding for initial plot establishment and data collection, and the US Forest Service provided funding for data collection in 2016 (Project \#15JV-11330136-044). The North Carolina Wildlife Resources Commission conducted the prescribed burns and assisted with general project management. This paper is based upon work supported by the USDA Hatch program, through the Clemson Experiment Station, under project number SC-1700514

Availability of data and materials Please contact author for data requests. 


\section{Declarations}

\section{Ethics approval and consent to participate}

Not applicable.

\section{Consent for publication}

Not applicable.

\section{Competing interests}

The authors declare that they have no competing interests.

\section{Author details}

${ }^{1}$ Department of Forestry and Environmental Conservation, Clemson University, 202 Lehotsky Hall, Clemson, South Carolina 29634-0331, USA 2USDA Forest Service (Retired), Southern Research Station, 233 Lehotsky Hall, Clemson, South Carolina 29634-0331, USA.

\section{Received: 14 April 2020 Accepted: 23 February 2021}

Published online: 23 March 2021

\section{References}

Ayers, H.B., and W.W. Ashe. 1905. The southern Appalachian forests. In US Geological Survey professional paper 37. Washington, D.C.: US Geologica Survey. https://doi.org/10.3133/pp37.

Azeria, E.T., M. Bouchard, D. Pothier, D. Fortin, and C. Hebert. 2011. Using biodiversity deconstruction to disentangle assembly and diversity dynamics of understorey plants along post-fire succession in boreal forest. Global Ecology and Biogeography 20: 119-133. https://doi.org/10.1111/j.1466-8238.2 010.00580.x.

Blankenship, B.A., and M.A. Arthur. 2006. Stand structure over 9 years in burned and fire-excluded oak stands on the Cumberland Plateau, Kentucky. Forest Ecology and Management 225: 134-145. https://doi.org/10.1016/j.foreco.2 005.12.032.

Boring, L.R., and W.T. Swank. 1984. The role of black locust (Robinia pseudoacacia) in forest succession. Journal of Ecology 72: 749-766. https://doi.org/10.23 $07 / 2259529$.

Brose, P.H., T. Schuler, D. Van Lear, and J. Berst. 2001. Bringing fire back: the changing regimes of the Appalachian mixed-oak forests. Journal of Forestry 99: 30-35.

Brose, P.H., and D.H. Van Lear. 1998. Responses of hardwood advance regeneration to seasonal prescribed fires in oak-dominated shelterwood stands. Canadian Journal of Forest Research 28 (3): 331-339. https://doi.org/1 $0.1139 / \times 97-218$

Burton, J.A., S.W. Hallgren, S.D. Fuhlendorf, and D.M. Leslie Jr. 2011. Understory response to varying fire frequencies after 20 years of prescribed burning in an upland oak forest. Plant Ecology 212 (9): 1513-1525. https://doi.org/10.1 007/s11258-011-9926-y.

Certini, G. 2005. Effects of fire on properties of forest soils: a review. Oecologia 143: 1-10. https://doi.org/10.1007/s00442-004-1788-8.

Chapman, G.L. 1950. The influence of mountain laurel undergrowth on environmental conditions and oak reproduction. Dissertation. New Haven: Yale University.

Christensen, N.L. 1993. The effects of fuel on nutrient cycles in longleaf pine ecosystems. In Proceedings of the 18th Tall Timbers Fire Ecology Conference, ed. S.M. Hermann, 205-214. Tallahassee: Tall Timbers Research Station.

Clarke, K.R. 1993. Non-parametric multivariate analyses of changes in community structure. Australian Journal of Ecology 18:117-117.

Clinton, B.D., and J.M. Vose. 2000. Plant succession and community restoration following felling and burning in the southern Appalachian Mountains. In Fire and forest ecology: innovative silviculture and vegetation management, Tall Timbers Fire Ecology Conference Proceedings No. 21, ed. W. Keith Moser and Cynthia F. Moser, 22-29. Tallahassee: Tall Timbers Research Station.

Costanza, J.K., J.W. Coulston, and D.N. Wear. 2017. An empirical, hierarchical typology of tree species assemblages for assessing forest dynamics under global change scenarios. PLOS ONE 12 (9). https://doi.org/10.1371/journal. pone.0184062.

De Cáceres, M., and P. Legendre. 2009. Associations between species and groups of sites: indices and statistical inference. Ecology 90 (12): 3566-3574. https:// doi.org/10.1890/08-1823.1.
Dey, D.C., and G. Hartman. 2005. Returning fire to Ozark Highland forest ecosystems: effects on advance regeneration. Forest Ecology and Management 217: 37-53. https://doi.org/10.1016/j.foreco.2005.05.002.

Dolan, M.M., and A.J. Parker. 2004. Evergreen understory dynamics in Coweeta Forest, North Carolina. Physical Geography 6: 481-498. https://doi.org/10.274 7/0272-3646.25.6.481.

Dufrêne, M., and P. Legendre. 1997. Species assemblages and indicator species: the need for a flexible asymetrical approach. Ecological Monographs 67: 345366. https://doi.org/10.1890/0012-9615(1997)067[0345:SAAIST]2.0.CO;2.

Elliott, K.J., R.L. Hendrick, A.E. Major, J.M. Vose, and W.T. Swank. 1999. Vegetation dynamics after a prescribed fire in the southern Appalachians. Forest Ecology and Management 114: 199-213. https://doi.org/10.1016/S0378-112 7(98)00351-X.

Elliott, K.J., and J.M. Vose. 2005. Effects of understory prescribed burning on shortleaf pine (Pinus echinata Mill.)/mixed-hardwood forests. Journal of the Torrey Botanical Society 132 (2): 236-251. https://doi.org/10.3159/1095-5674 (2005) 132[236:EOUPBO]2.0.CO;2.

Faith, D.P., P.R. Minchin, and L. Belbin. 1987. Compositional dissimilarity as a robust measure of ecological distance. Vegetatio 69: 57-68. https://doi.org/1 $0.1007 / B F 00038687$

Garren, K.H. 1943. Effects of fire on vegetation of the southeastern United States. Botanical Review 9 (9): 617-654. https://doi.org/10.1007/BF02872506.

Gilliam, F.S., and M.R. Roberts. 2003. The dynamic nature of the herbaceous layer: synthesis and future directions for research. In The herbaceous layer in forests of eastern North America, ed. F.S. Gilliam and M.R. Roberts, 323-337. New York: Oxford University Press.

Gonzalez-Tagle, M.A., L. Schwendenmann, J.J. Perez, and R. Schulz. 2008. Forest structure and woody plant species composition along a fire chronosequence in mixed pine-oak forest in the Sierra Madre Oriental, northeast Mexico. Forest Ecology and Management 256: 161-167. https://doi.org/10.1016/j. foreco.2008.04.021

Greenberg, C.H., B.S. Collins, W.H. McNab, D.K. Miller, and G.R. Wein. 2016 Introduction to natural disturbances and historic range of variation: type, frequency, severity, and post-disturbance structure in Central hardwood forests. In Natural disturbances and historic range of variation. Managing forest ecosystems, ed. C.H. Greenberg and B.S. Collins, vol. 32, 1-32. Cham: Springer. https://doi.org/10.1007/978-3-319-21527-3_1.

Holzmueller, E.J., J.W. Groninger, and C.M. Ruffner. 2014. Facilitating oak and hickory regeneration in mature Central hardwood forests. Forests. 5: 33443351. https://doi.org/10.3390/ 55123344 .

Horn, H.S. 1974. The ecology of secondary succession. Annual Review of Ecological Systems 5: 25-37. https://doi.org/10.1146/annurev.es.05.110174.000325.

Huddle, J., and S.G. Pallardy. 1999. Effect of fire on survival and growth of Acer rubrum and Quercus seedlings. Forest Ecology and Management 118 (1): 4956. https://doi.org/10.1016/S0378-1127(98)00485-X.

Hutchinson, T.F., R.E.J. Boerner, L.R. Iverson, S. Sutherland, and E.K. Sutherland. 1999. Landscape patterns of understory composition and richness across a moisture and nitrogen mineralization gradient in Ohio (USA) Quercus forests. Plant Ecology 144: 179-189. https://doi.org/10.1 023/A:1009804020976.

Hutchinson, T.F. R.E.J. Boerner, S. Sutherland, E.K. Sutherland, M. Ortt, and L.R. Iverson. 2005. Prescribed fire effects on the herbaceous layer of mixed-oak forests. Canadian Journal of Forest Resources 35: 877-890. https://doi.org/1 $0.1139 / \times 04-189$

Iverson, L.R., T.F. Hutchinson, A.M. Prasad, and M.P. Peters. 2008. Thinning, fire, and oak regeneration across a heterogeneous landscape in the eastern US: 7-year results. Forest Ecology and Management 255: 3035-3050. https://doi. org/10.1016/j.foreco.2007.09.088.

Kane, J.M., J.M. Varner, E.E. Knapp, and R.F. Powers. 2010. Understory vegetation response to mechanical mastication and other fuels treatments in a ponderosa pine forest. Applied Vegetation Science 12 (2): 207-220. https://doi. org/10.1111/j.1654-109X.2009.01062.x.

Keyser, M.J., P.J. Gould, M.E. McDill, K.C. Steiner, and J.C. Finley. 2008. Classifying patterns of understory vegetation in mixed-oak forests in two ecoregions of Pennsylvania. Northern Journal of Applied Forestry 25 (1): 38-44. https://doi. org/10.1093/njaf/25.1.38.

Kruskal, J.B. 1964a. Multidimensional scaling by optimizing goodness of fit to a nonmetric hypothesis. Psychometrika 29: 1-27. https://doi.org/10.1007/BF022 89565.

Kruskal, J.B. 1964b. Nonmetric multidimensional scaling: a numerical method. Psychometrika 29: 115-129. https://doi.org/10.1007/BF02289694. 
Kuddes-Fischer, L.M., and M.A. Arthur. 2002. Response of understory vegetation and tree regeneration to a single prescribed fire in oak-pine forests. Natural Areas Journal 22 (1): 43-52.

Lafon, C.W., A.T. Naito, H.D. Grissino-Mayer, S.P. Horn, and T.A. Waldrop. 2017. Fire history of the Appalachian region: a review and synthesis. In USDA Forest Service General Technical Report SRS-219, Southern Research Station, Asheville, North Carolina, USA

Maechler, M., P. Rousseeuw, A. Struyf, M. Hubert, and K. Hornik. 2015. cluster: Cluster Analysis Basics and Extensions. R package version 2.0.3.

McCune, B., and J.B. Grace. 2002. Analysis of ecological communities. Gleneden Beach: MjM Software Design.

McCune, B., R. Rosentreter, J.M. Ponzetti, and D.C. Shaw. 2000. Epiphyte habitats in an old conifer forest in western Washington, USA. The Bryologist 103 (3): 417-427. https://doi.org/10.1639/0007-2745(2000)103[0417:EHIAOC]2.0.CO;2.

Monk, C.D., D.T. McGinty, and F.P. Day. 1985. The ecological importance of Kalmia latifolia and Rhododendron maximum in the deciduous forest of the Southern Appalachians. Bulletin of the Torrey Botanical Club 112: 187-193. https://doi.org/10.2307/2996415.

Moser, W.K., M.J. Ducey, and P.M.S. Ashton. 1996. Effects of fire intensity on competitive dynamics between red and black oaks and mountain laurel. Northern Journal of Applied Forestry 13 (3): 119-123. https://doi.org/10.1093/ njaf/13.3.119.

NatureServe. 2020. NatureServe Explorer. Arlington: NatureServe https://explorer.na tureserve.org/ Accessed 21 Oct 2020

Nowacki, G.J., and M.D. Abrams. 2008. The demise of fire and mesophication of forests in the eastern United States. Bioscience 58 (2): 123-138. https://doi. org/10.1641/B580207.

Oakman, E.C., D.L. Hagan, T.A. Waldrop, and K. Barrett. 2019. Understory vegetation responses to 15 years of repeated fuel reduction treatments in the Southern Appalachian Mountains, USA. Forests 10 (14): 350. https://doi. org/10.3390/f10040350

Oksanen, J., F. Guillaume Blanchet, M. Friendly, R. Kindt, P. Legendre, D. McGlinn, P.R. Minchin, R.B. O'Hara, G.L. Simpson, P. Solymos, M.H.H. Stevens, E. Szoecs, and H. Wagner. 2015. Vegan: the community ecology package, v. 1.8-4.

Pavlovic, N.B., S.A. Leicht-Young, and R. Grundel. 2011. Short-term effects of burn season on flowering phenology of savanna plants. Plant Ecology 212: 611625. https://doi.org/10.1007/s11258-010-9851-5.

Peterson, D.W., P.B. Reich, and K.J. Wrage. 2007. Plant functional group responses to fire frequency and tree canopy cover gradients in oak savannas and woodlands. Journal of Vegetation Science 18 (1): 3-12. https://doi.org/10.1111/ j.1654-1103.2007.tb02510.x.

Phillips, R., T. Hutchinson, L. Brudnak, and T. Waldrop. 2007. Fire and fire surrogate treatments in mixed-oak forests: effects on herbaceous layer vegetation. In The fire environment-innovations, management, and policy; conference proceedings, Proceedings RMRS-P-46, ed. B.W. Butler and W. Cook. Fort Collins: USDA Forest Service, Rocky Mountain Research Station.

Pickett, S.T.A., J. Wu, and M.L. Cadenasso. 1999. Patch dynamics and the ecology of disturbed ground: a framework for synthesis. In Ecosystems of disturbed ground, ed. L.R. Walker, 707-722. Amsterdam: Elsevier.

Pyne, S.J. 1997. Fire in America: a cultural history of wildland and rural fire. 2nd ed. Seattle: University of Washington Press.

R Core Team. 2016. R: a language and environment for statistical computing. $R$ Foundation for Statistical Computing, Vienna, Austria. https://www.R-project.org/.

Roberts, M.R. 2004. Response of herbaceous layer to natural disturbance in North American forests. Canadian Journal of Botany 82: 1273-1283. https://doi.org/1 0.1139/b04-091.

Schwilk, D.W., J.E. Keeley, E.E. Knapp, J. Mclver, J.D. Bailey, C.J. Fettig, C.E. Fiedler, R.J. Harrod, J.J. Moghaddas, K.W. Outcalt, C.N. Skinner, S.L. Stephens, T.A. Waldrop, D. A. Yaussy, and A. Youngblood. 2009. The national fire and fire surrogate study: effects of fuel reduction methods on forest vegetation structure and fuels. Ecological Applications 19: 285-304. https://doi.org/10.1890/07-1747.1.

Shearman, T.M., G.G. Wang, R.K. Peet, T.R. Wentworth, M.P. Schafale, and A.S. Weakley. 2017. A community analysis for forest ecosystems with natural growth of Persea spp. in the southeastern United States. Castanea 83 (1): 3 27. https://doi.org/10.2179/17-131.

Small, C.J., and B.C. McCarthy. 2002. Spatial and temporal variation in the response of understory vegetation to disturbance in a central Appalachian oak forest. Journal of the Torrey Botanical Society 129: 136-153. https://doi. org/10.2307/3088727.

Stanturf, J.A., D.D. Wade, T.A. Waldrop, D.K. Kennard, and G.L. Achtemeier. 2002. Fire in Southern forest landscapes. In Southern forest resource assessment.
USDA Forest Service General Technical Report SRS-53, ed. D.M. Wear and J. Greis, 607-630. Asheville: USDA Forest Service, Southern Research Station.

Stephens, S.L., J.D. Mclver, R.E.J. Boerner, C.J. Fettig, J.B. Fontaine, B.R. Hartsough, P.L. Kennedy, and D.W. Schwilk. 2012. The effects of forest fuel reduction treatments in the United States. Bioscience 62: 549-560. https://doi.org/10.152 5/bio.2012.62.6.6

Taylor, A.H. 2007. Forest changes since Euro-American settlement and ecosystem restoration in the Lake Tahoe Basin, USA. In Restoring fire-adapted ecosystems: proceedings of the 2005 national silviculture workshop, USDA Forest Service General Technical Report PSW-GTR-203, ed. R.F. Powers, 3-20. Albany: USDA Forest Service, Pacific Southwest Research Station.

Van Lear, D.H., P.H. Brose, and P.D. Keyser. 2000. Using prescribed fire to regenerate oaks. In Proceedings: workshop on fire, people, and the central hardwoods landscape; 12-14 March 2000; Richmond, Kentucky, USDA Forest Service General Technical Report NE-274, ed. D.A. Yaussy, 97-102. Newtown Square: USDA Forest Service. https://doi.org/10.2737/NE-GTR-274.

Van Lear, D.H., and T.A. Waldrop. 1989. History, use, and effects of fire in the Appalachians. USDA Forest Service General Technical Report SE-54. Asheville: USDA Forest Service, Southeastern Forest Experiment Station. https://doi. org/10.2737/SE-GTR-54.

Vose, J.M., B.D. Clinton, and W.T. Swank. 1993. Fire, drought, and forest management influences on pine/hardwood ecosystems in the Southern Appalachians. In A paper presented at the 12th Conference on Fire and Forest Meteorology, 26 to 28 October 1993, at Jekyll Island, Georgia, USA. Miscellaneous publication 4726. Asheville: USDA Forest Service, Southern Research Station https://www.srs.fs.usda.gov/pubs/4726.

Waldrop, T.A., D. Hagan, and D.M. Simon. 2016. Repeated application of fuel reduction techniques in the southern Appalachian Mountains, USA: implications for achieving management goals. Fire Ecology 12 (2): 28-47. https://doi.org/10.4996/fireecology.1202028.

Waldrop, T.A., H.H. Mohr, R.J. Phillips, and D.M. Simon. 2014. The National Fire and Fire Surrogate Study: vegetation changes over 11 years of fuel reduction treatments in the Southern Appalachian Mountains. In Proceedings-wildland fire in the Appalachians: discussions among managers and scientists, General Technical Report SRS-199, ed. T.A. Waldrop, 34-41. Asheville: USDA Forest Service, Southern Research Station.

Waldrop, T.A., D.A. Yaussy, R.J. Phillips, T.F. Hutchinson, L. Brudnak, and R.E.J. Boerner. 2008. Fuel reduction treatments affect stand structure of hardwood forests in western North Carolina and southern Ohio, USA. Forest Ecology and Management 255: 3117-3129. https://doi.org/10.1016/j.foreco.2007.11.010.

Web Soil Survey. 2020. Web Soil Survey home page. http://websoilsurvey.sc.egov. usda.gov/. Accessed 21 Oct 2020.

Willig, M.R., and L.R. Walker. 1999. Disturbance in terrestrial ecosystems: salient themes, synthesis, and future directions. In Ecosystems of disturbed ground, volume 16, chapter 33, ed. L.R. Walker, 747-767. Amsterdam: Elsevier.

\section{Publisher's Note}

Springer Nature remains neutral with regard to jurisdictional claims in published maps and institutional affiliations.

\section{Submit your manuscript to a SpringerOpen ${ }^{\circ}$ journal and benefit from:}

- Convenient online submission

- Rigorous peer review

- Open access: articles freely available online

- High visibility within the field

- Retaining the copyright to your article

Submit your next manuscript at $>$ springeropen.com 